Shnyrkov Olexandr, $\mathrm{PhD}$ in Economics, Associate Professor, Kyiv National University of Trade and Economics,

Kyiv, Ukraine

ORCID: 0000-0002-2493-4284

Resarcher ID: M-3302-2016

\title{
THE IMPACT OF US ECONOMIC SANCTIONS ON RUSSIA'S SOCIAL- ECONOMIC DEVELOPMENT
}

The article covers the main theoretical and historical aspects of economic sanctions. There are given the classification of economic sanctions and examples of their application in modern international relationships. The reasons, essence and results of the application of US sanctions to the Russian Federation are considered.

Keywords: sanctions, widespread poverty, devaluation of ruble, capital flight.

\section{Шнирков Олександр. Вплив економічних санкцій США на розвиток економіки Росї.}

У статті висвітлюються основні теоретичні та історичні аспекти економічних санкиій. Наведена класифікація економічних санкцій та приклади їх застосування у сучасних міжнародних відносинах. Розглянуто причини, сутність та результати застосування санкцій Сполучених Штатів Америки щодо Російської Федерачіï.

Relevance of research topic. Economic sanctions are the one of the mechanism of economically developed countries to make influence on the behavior of other states, to show their leadership, and to seek to induce on the social and political change in that country.

The US sanctions on Russia economy aims to change the Russian government's policy towards Ukrainian issue by putting pressure on the Russian economy. Targeted sanctions on individuals, organizations, and sectors have been aimed at increasing Russia's political isolation and increasing Russia's economic losses, especially in areas of strategic importance to the Russian economy.

Formulation of the problem. United States sanctions, imposed on Russia since 2014 in response to Moscow's role in the conflict in south-east Ukraine, have now entered their fifth year. They appear to have been effective on several fronts, despite the ongoing nature of the crisis.

Based on the above, we can formulate the following goals of this research:

1) mechanics and legal underpinnings;

2) effectiveness and impact;

3) economic costs to the Russian economy at the national, sectoral, state and firm levels. 
Analysis of recent researches and publications. A number of scientific works has been devoted to the problems of US sanctions against Russia. Thus, R. Nelson (2017) describes the impact of US economic sanctions on Russia's finance sector. Erica Moret, Francesco Giumelli, Dawid Jarosz indicates increasing poverty in Russia due to the economic sanctions.

The existing scientific findings have not fully reflected the problem of the US economic sanctions against Russia. This is what made the research relevant.

Presenting main material. Economic sanctions are the means of economically developed countries to influence the behavior of other states, to show leadership, and to seek to induce on the social or political change in that country [1].

The application of US sanctions on Russia aims to change the Russian government's policy on the Ukrainian issue by putting pressure on the Russian economy. Targeted sanctions on individuals, organizations, and sectors have been aimed at increasing Russia's political isolation and increasing Russia's economic losses, especially in areas of strategic importance to the Russian economy.

In particular, Russia grappled with:

I. economic contraction, with growth slowing to $0.7 \%$ in 2014 , before contracting sharply by $3.7 \%$ in 2015 ;

II. capital flight, with net private capital outflows from Russia totaling $\$ 152$ billion in 2014, compared to $\$ 61$ billion in 2013;

III. rapid depreciation of the ruble, more than $50 \%$ against the dollar over the course of 2015;

IV. a higher rate of inflation, from $6.8 \%$ in 2013 to $15.5 \%$ in 2015 ;

$\mathrm{V}$. budgetary pressures, with the budget deficit widening to $3.2 \%$ in 2015 , up from $0.9 \%$ in 2013 ;

VI. tapping international reserve holdings to offset fiscal challenges, including exclusion from international capital markets, as reserves fell from almost $\$ 500$ billion at the start of 2014 to $\$ 368$ billion at the end of 2015 ; and

VII. more widespread poverty, which increased by 3.1 million to 19.2 million in 2015 (13.4\% of the population). [2]

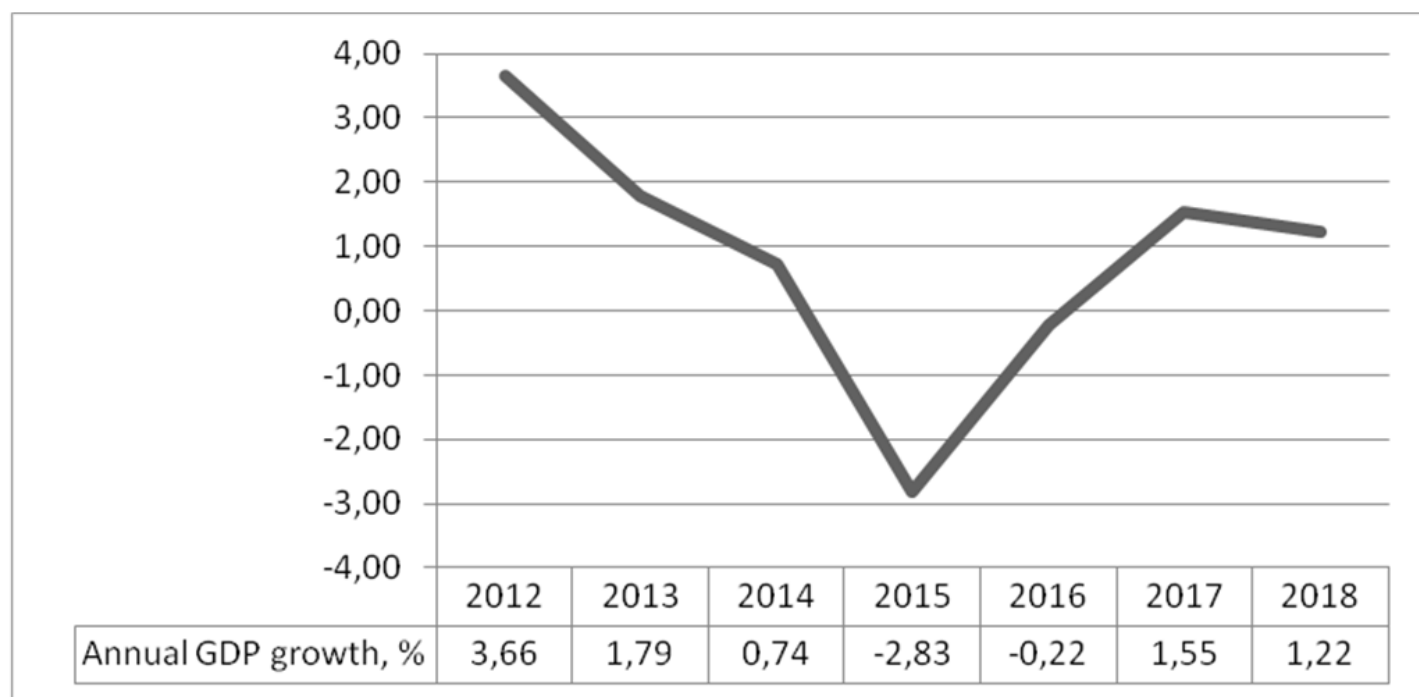

Fig. 1. Russia's GDP annual growth 2012-2018 [3] 
During 2016, Russia's economy largely stabilized, even as the sanctions remained in place. Russia's economy contracted at a slower rate $(0.8 \%)$; net private sector capital outflows slowed, from over $\$ 150$ billion in 2014 to $\$ 15$ billion in 2016; inflation fell by more than half, to $7.2 \%$; the value of the ruble stabilized; and the government successfully sold new bonds in international capital markets in May 2016 for the first time since the sanctions were imposed.

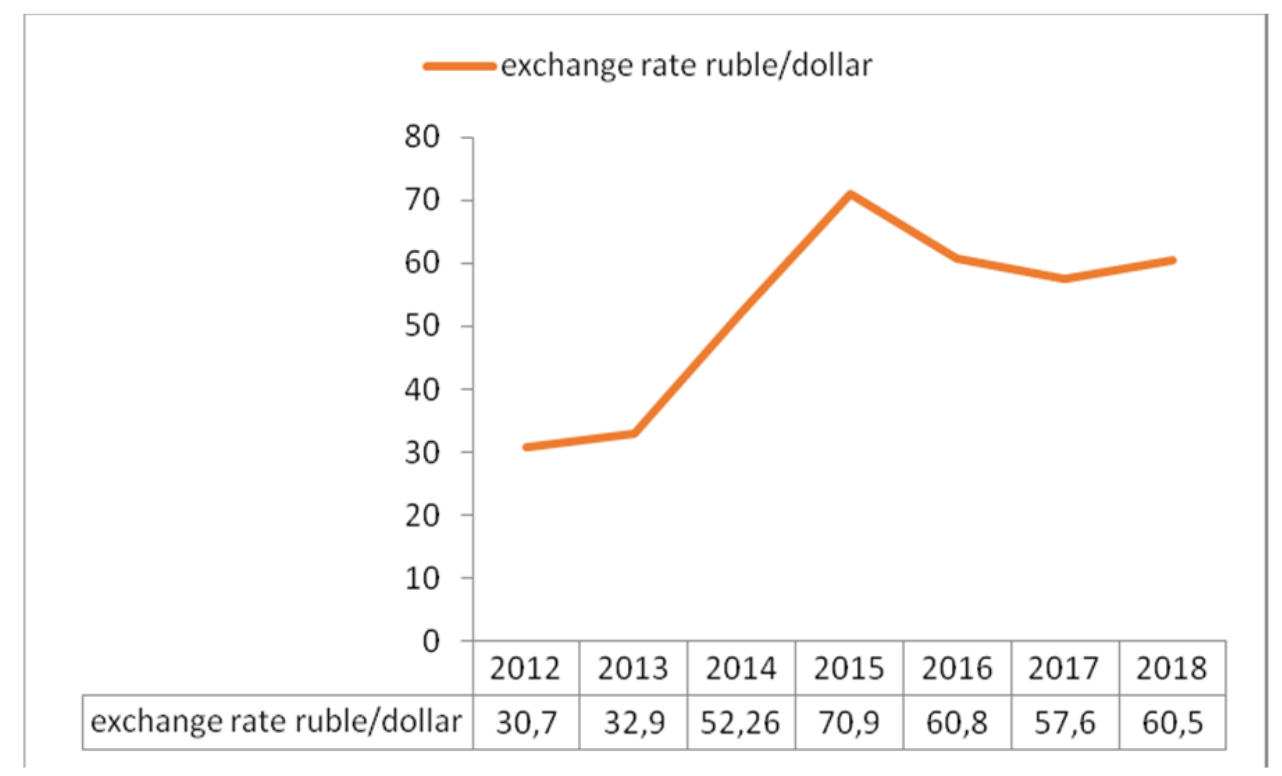

Fig. 2. The rapid devaluation of the ruble [3]

Russia's economy faced a number of challenges in 2014 and 2015, including capital flight, depreciation of the ruble, rising inflation, weaker growth prospects, and budgetary pressures. Many experts believe that sanctions are contributing to Russia's economic challenges. However, it is difficult to assess the impact of sanctions separate from other domestic and international factors, particularly low oil prices.

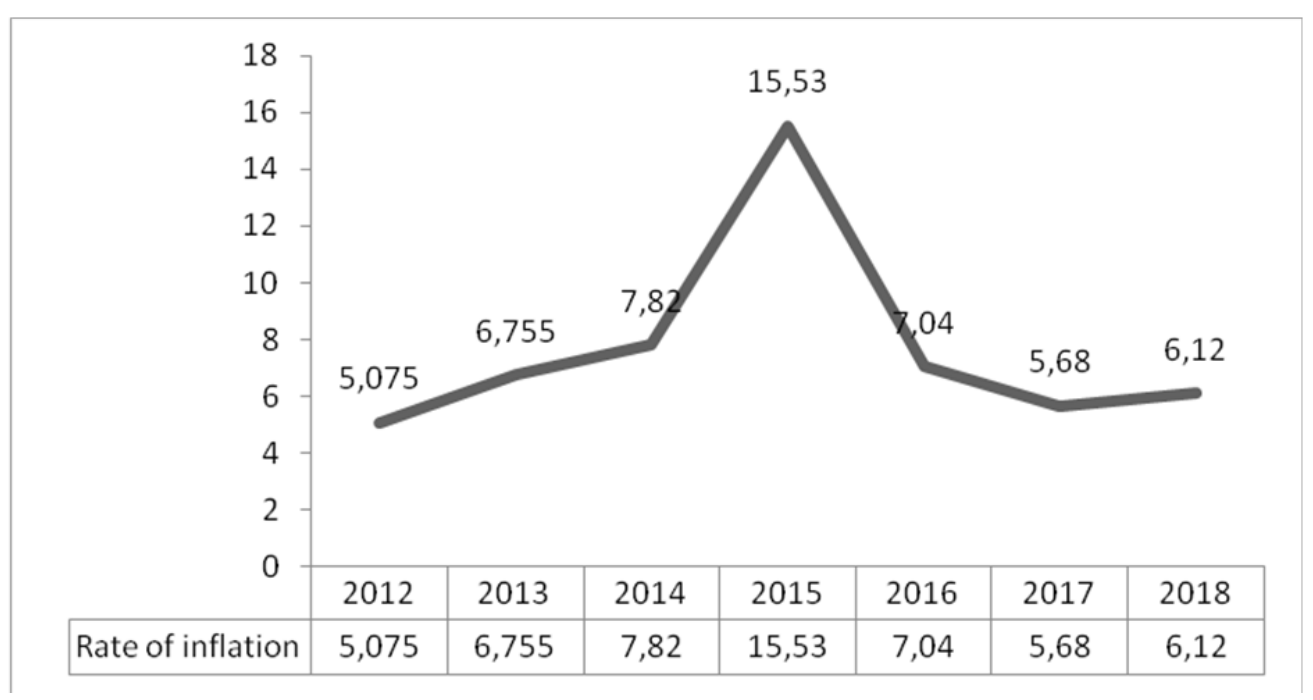

Fig. 3. The great level of inflation. [3] 
Since 2016, the economic situation in Russia has largely stabilized, despite the fact that sanctions are still in place. This was mainly due to the rise of world oil and natural gas prices.

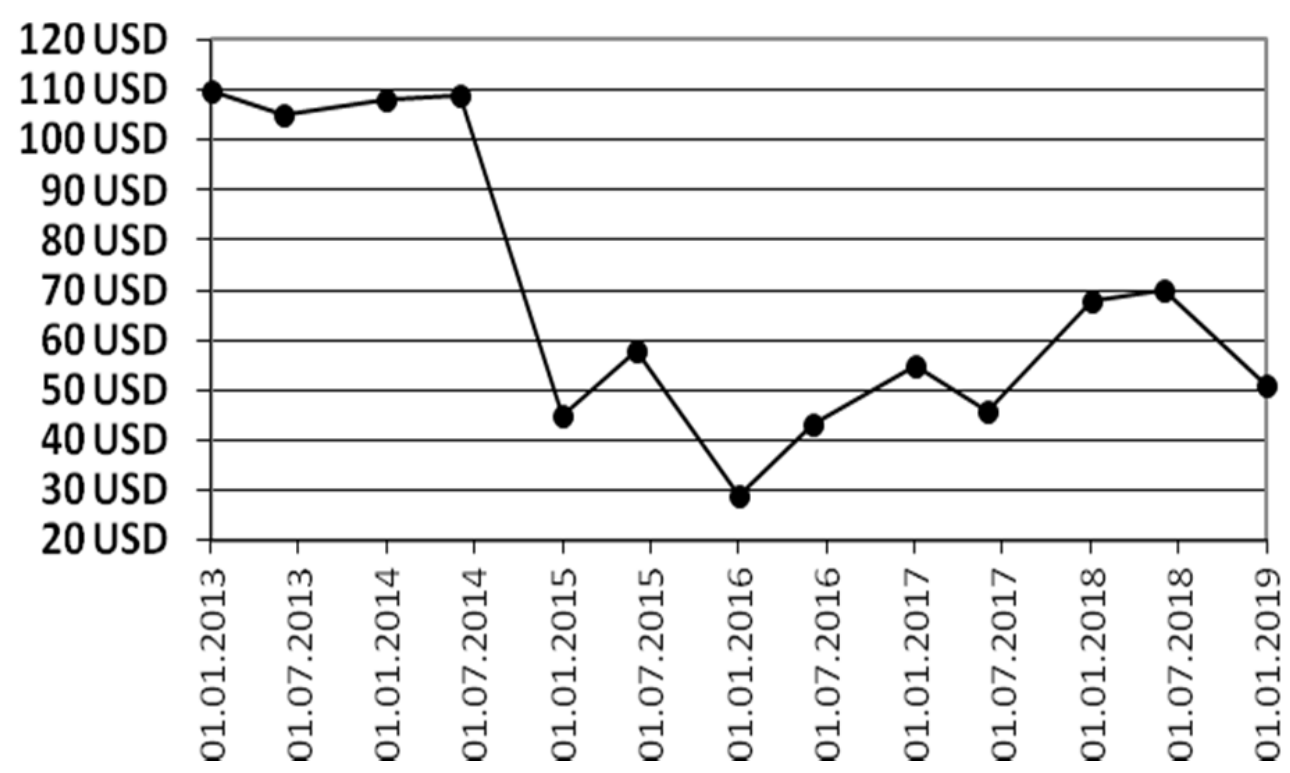

Figure 4. Changes in the price of BRENT oil 2014-2018, USD. [3]

The oil and gas sector is an important focus of Russia's economy, as exports of these goods account for more than half of total exports and account for over $30 \%$ of the country's gross domestic product.

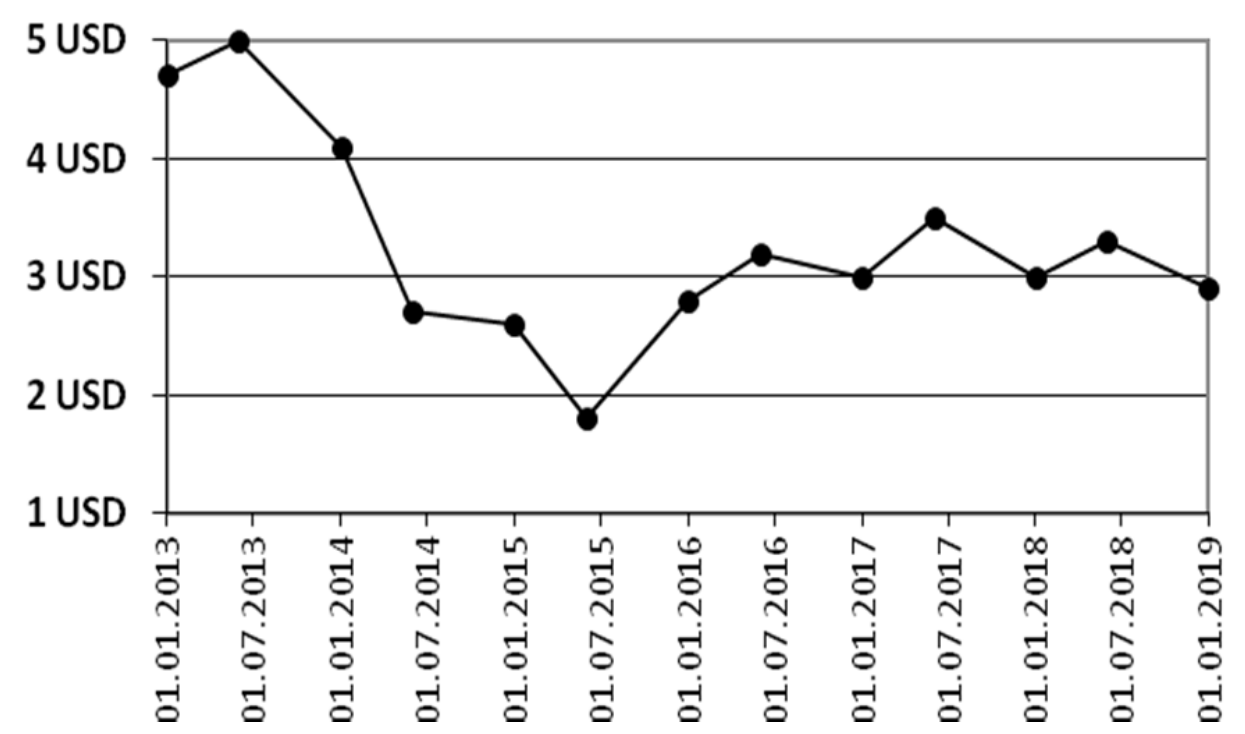

Figure 5. Changes in the price of natural gas 2014-2018, USD. mmbtu. [3]

Conclusion. The United States, in coordination with the EU, implemented targeted sanctions on key Russian individuals, entities, and sectors in response to Russia's actions in Ukraine. U.S. sanctions include, for example, targeting officials in 
Putin's inner circle and placing restrictions on new debt to specific financial institutions.

The effectiveness of the sanctions in inducing a change in the behavior of the Russian government remains to be seen. Although the Russian government continues to face a number of economic challenges, many of which are unrelated to sanctions, economic forecasts suggest that the Russian economy is stabilizing and there is some evidence that investor sentiment toward Russia may be improving.

\section{REFERENCES}

1. Consolidated united nations security council sanctions list. URL: [Електронний pecypc] - Режим доступу : https://www.un.org/sc/suborg/en/ sanctions/un-sc-consolidated-list

2. European Union: Newsroom. [Електронний ресурс] - Режим доступу: URL: https://europa.eu/newsroom

3. Nelson R. M. U.S. sanctions and Russia's economy. Washington, DC: Congressional Research Service; 2017.[Електронний ресурс] - Режим доступу : URL: https://fas.org/sgp/crs/row/R 43895.pdf

4. The World Bank. [Електронний ресурс] - Режим доступу :URL : https://data.worldbank.org/indicator 